\title{
Rhodovulum imhoffii sp. nov.
}

\author{
Correspondence \\ Ch. Sasikala \\ r449@sify.com or \\ sasi449@yahoo.ie
}

\author{
T. N. R. Srinivas, ${ }^{1}$ P. Anil Kumar, ${ }^{1}$ Ch. Sasikala ${ }^{1}$ and Ch. V. Ramana ${ }^{2}$ \\ ${ }^{1}$ Environmental Microbial Biotechnology Laboratory, Centre for Environment, Institute of \\ Science and Technology, JNT University, Kukatpally, Hyderabad 500 072, India \\ ${ }^{2}$ Department of Plant Sciences, School of Life Sciences, University of Hyderabad, PO Central \\ University, Hyderabad 500 046, India
}

\begin{abstract}
A yellowish-brown bacterium was isolated from photoheterotrophic enrichment cultures obtained from water samples of an aquaculture pond at Bhimunipatnam, India. Enrichment and isolation in a medium containing $2 \% \mathrm{NaCl}(\mathrm{w} / \mathrm{v})$ yielded strain $\mathrm{JA} 125^{\top}$, the cells of which were rod-shaped and non-motile. On the basis of the $16 \mathrm{~S}$ rRNA gene sequence, strain JA125 ${ }^{\top}$ belongs to the class Alphaproteobacteria and is closely related to the type strains of Rhodovulum iodosum (96\%), Rhodovulum adriaticum (95\%), Rhodovulum robiginosum (95\%), Rhodovulum sulfidophilum (94\%) and Rhodovulum marinum (94\%). The cells of strain JA125 ${ }^{\top}$ contained vesicular internal membranes and bacteriochlorophyll a and carotenoids of the spheroidene series. Strain JA125 ${ }^{\top}$ grew optimally at $28^{\circ} \mathrm{C}$ and at $\mathrm{pH}$ 7.0-8.0. The best growth occurred photoheterotrophically with a number of organic compounds serving as carbon sources and electron donors. The strain grew photoautotrophically, but chemoautotrophic growth did not occur. Strain JA125 ${ }^{\top}$ was able to utilize sulfide, sulfate, thiosulfate and thioglycolate as sulfur sources. Biotin was required as a growth factor. The DNA G +C content was 58 mol\%. On the basis of $16 \mathrm{~S}$ rRNA gene sequence analysis and the morphological and physiological data, strain $\mathrm{JA} 125^{\mathrm{T}}$ is significantly different from other species of the genus Rhodovulum and represents a novel species, for which the name Rhodovulum imhoffii sp. nov. is proposed. The type strain is $\mathrm{JA} 125^{\top}\left(=\mathrm{JCM} 13589^{\top}=\mathrm{DSM} 18064^{\top}\right)$.
\end{abstract}

The genus Rhodovulum was created to separate the marine species of the genus Rhodobacter from their freshwater counterparts (Hiraishi \& Ueda, 1994). The genus Rhodovulum currently comprises seven species: Rhodovulum sulfdophilum (originally described as Rhodopseudomonas sulfidophila; Hansen \& Veldkamp, 1973), Rhodovulum adriaticum (originally described as Rhodopseudomonas adriatica; Neutzling et al., 1984), Rhodovulum euryhalinum (originally described as Rhodobacter euryhalinus; Kompantseva, 1985), Rhodovulum strictum (Hiraishi \& Ueda, 1995), Rhodovulum iodosum and Rhodovulum robiginosum (Straub et al., 1999) and Rhodovulum marinum (Srinivas et al., 2006). In this communication, we propose a novel species of the genus Rhodovulum.

Water samples from an aquaculture pond near the sea (Bay of Bengal) at Bhimunipatnam, India, were collected in a sterile polypropylene bottle. The medium of Pfennig (Pfennig \& Trüper, 1992), supplemented with $\mathrm{NaCl}(2 \%$, $\mathrm{w} / \mathrm{v})$, pyruvate $(0.3 \%, \mathrm{w} / \mathrm{v})$ as a carbon source and ammonium chloride $(0.12 \%)$ as a nitrogen source, was used for photoheterotrophic growth in the light $(2400 \mathrm{~lx})$ at

The GenBank/EMBL/DDBJ accession number for the $16 \mathrm{~S}$ rRNA gene sequence of strain $\mathrm{JA} 125^{\top}$ is $\mathrm{AM} 180953$.

Phase-contrast/electron photomicrographs and absorption spectra of strain $\mathrm{JA} 125^{\top}$ are available as supplementary figures in IJSEM Online.
$30 \pm 2{ }^{\circ} \mathrm{C}$. Purification was achieved by using the repeated agar shake dilution method (Pfennig \& Trüper, 1992; Imhoff, 1988). Purified cultures were grown in completely filled screw-capped test tubes $(10 \times 100 \mathrm{~mm})$ for photoheterotrophic growth.

Morphological properties (cell shape, cell division, cell size) were observed by using phase-contrast light microscopy (BH-2; Olympus), and intracytoplasmic structures such as the internal membrane system were viewed from ultrathin sections through a transmission electron microscope $(\mathrm{H}-$ 7500; Hitachi). In vivo absorption spectra were measured with a Spectronic Genesys 2 spectrophotometer in sucrose solution (Trüper \& Pfennig, 1981). Absorption spectra were also recorded from pigments extracted with acetone after elution of the cell suspension with acetone through a $10 \times 200 \mathrm{~mm}$ column packed with aluminium oxide. The utilization of organic compounds as carbon sources/ electron donors for phototrophic growth was tested in the presence of yeast extract $(0.03 \%, w / v)$ without any additional carbon source/electron donor. The concentrations of these compounds were $0.1 \%(\mathrm{v} / \mathrm{v}$ ) (for formic acid, propionate, butyrate, caproate, valerate, lactate, glycerol, methanol and ethanol) and $0.3 \%(\mathrm{w} / \mathrm{v})$ (for the other organic compounds tested), $1 \mathrm{mM}$ benzoate and $0.1 \%$ $\mathrm{NaHCO}_{3}$. To test sulfur-source utilization, $\mathrm{MgSO}_{4}$ was replaced by $\mathrm{MgCl}_{2}(0.01 \%)$ and then various sulfur sources 
$\left[\mathrm{Na}_{2} \mathrm{~S}, \mathrm{Na}_{2} \mathrm{~S}_{2} \mathrm{O}_{3}\right.$, sodium thioglycolate, cysteine, $\mathrm{MgSO}_{4}$ $(0.5 \mathrm{mM})$ or $\left.\mathrm{FeSO}_{4}(10 \mathrm{mM})\right]$ were added to the medium. Nitrogen-source utilization was tested by replacing ammonium chloride with different nitrogen sources $(0.12 \%, \mathrm{w} / \mathrm{v})$. Vitamin requirements were tested by replacing the yeast extract with single vitamins and combinations of vitamins as growth factors. Chemotrophy was assessed by growing the cultures at $30^{\circ} \mathrm{C}$ in the dark in Erlenmeyer flasks placed in an orbital shaker. Diazotrophy was assessed by determining growth in an $\mathrm{N}_{2}$ atmosphere in medium devoid of a combined nitrogen source, and was confirmed by repeated subculturing (four times). Growth was measured turbidometrically at $660 \mathrm{~nm}$ (using a Systronics colorimeter).

The genomic DNA was extracted and purified according to the method of Marmur (1961) and the G+C content (mol\%) was determined by HPLC (Mesbah et al., 1989). Cell material for 16S rRNA gene sequencing was taken from 1-2 ml well-grown liquid culture. DNA was extracted and purified by using the Qiagen genomic DNA extraction kit. PCR amplification and 16S rRNA gene sequencing were performed as described previously (Imhoff et al., 1998; Imhoff \& Pfennig, 2001). Sequences were aligned using the CLUSTAL W program (Thompson et al., 1994) and the alignment was corrected manually. The CLUSTAL $\mathrm{W}$ alignment file was used as input file to the SEQBOOT program in the PHYLIP package and the output file of SEQBOOT was used as the input file for maximum-likelihood analysis with 100 datasets and five times jumbling. One single tree was generated using 100 trees generated during maximumlikelihood analysis using the CONSENSE program. The distance matrix was calculated on the basis of the algorithm of Jukes \& Cantor (1969) with the DNADIST program within the PHYLIP package (Felsenstein, 1989). The FITCH program in the PHYLIP package was employed to fit a tree to the evolutionary distances using the DIST file as infile and the CONSENSE file as intree.

Samples were collected on 24 February 2005 at around midday from an aquaculture pond near the sea (Bay of Bengal) at Bhimunipatnam, India; the GPS positioning of the sample collection site was $17^{\circ} 51^{\prime} 41.03^{\prime \prime} \mathrm{N} 83^{\circ} 25^{\prime} 16.81^{\prime \prime}$ E. The sample that yielded strain $\mathrm{JA} 125^{\mathrm{T}}$ had a $\mathrm{pH}$ of 6.8 , a salinity of $1-2 \% \mathrm{NaCl}$ and a temperature of $30-35^{\circ} \mathrm{C}$. The sample was inoculated into a sterile screw-capped tube filled with the medium for photoheterotrophic growth; incubation was for 1 week in the light, with intermittent shaking. Yellowish-brown enrichments were obtained and subcultured into the same medium. This culture was used for purification in a subsequent agar shake dilution series. After 4 days incubation, small, convex, yellowish-brown colonies at the bottom and pinkish colonies at the top (due to the diffusion of oxygen) were observed. The colony and cell morphologies were the same in all dilution series. The culture was maintained by repeated subculturing in the same medium and also in stab cultures. Stab cultures were preserved in a refrigerator at $4{ }^{\circ} \mathrm{C}$. Individual cells of strain JA12 $25^{\mathrm{T}}$ were rod-shaped (see Supplementary Fig. S1 available in IJSEM Online), $0.5 \mu \mathrm{m}$ wide and $1 \mu \mathrm{m}$ long. The cells were non-motile and multiplied by binary fission. Electron microphotographs of ultrathin sections of the cells revealed vesicular-type internal membranes (Supplementary Fig. S2).

Strain $\mathrm{JA} 25^{\mathrm{T}}$ grows well photoorganoheterotrophically (optimum light intensity is $2400 \mathrm{~lx}$ ) and chemoorganoheterotrophically (aerobically in the dark). It tolerates atmospheric oxygen levels. Strain $\mathrm{JA}_{12} 5^{\mathrm{T}}$ was able to grow photolithoautotrophically [anaerobically in the light (2400 lx) with $\mathrm{Na}_{2} \mathrm{~S} .9 \mathrm{H}_{2} \mathrm{O}$ or $\mathrm{Na}_{2} \mathrm{~S}_{2} \mathrm{O}_{3}(0.5 \mathrm{mM})$ as the electron donor and $\mathrm{NaHCO}_{3}(0.1 \%$, w/v) $)$. Chemolithoautotrophy [aerobically in the dark with thiosulfate $(0.5 \mathrm{mM})$ as electron donor and $\left.\mathrm{NaHCO}_{3}(0.1 \% \mathrm{w} / \mathrm{v})\right]$ could not be demonstrated. The substrates that were utilized (Table 1) as carbon/electron donors under photoorganoheterotrophic conditions included acetate, pyruvate, succinate, fumarate, glycerol, glutamate, $\alpha$-ketoglutaric acid, malate, caproate and Casamino acids. Those which could not be utilized included oleic acid, citrate, glucose, sucrose, lactose, maltose, starch, mannitol, sorbitol, ethanol, formic acid, lactic acid, citrate, sodium potassium tartrate, benzoate and cysteine. Thiosulfate, sulfate, thioglycolate and sodium sulfide were utilized as sulfur sources under photoheterotrophic conditions. Ammonium chloride, molecular nitrogen, glutamate, glutamine and urea were utilized as nitrogen sources, but nitrate and nitrite did not support growth. Salt is obligatory for the growth of strain JA $125^{\mathrm{T}}$ : growth occurs at $0.05-7 \% \mathrm{NaCl}(\mathrm{w} / \mathrm{v})$, with an optimum at $0.5-4 \%(\mathrm{w} / \mathrm{v})$. This situation is similar to that observed for the growth of other marine isolates from India, Marichromatium indicum $\mathrm{JA} 100^{\mathrm{T}}$ (Arunasri et al., 2005) and Rhodovulum marinum $\mathrm{JA}_{128}{ }^{\mathrm{T}}$ (Srinivas et al., 2006), which also grow with $\mathrm{NaCl}$ concentrations in the range $0.05-8 \% \mathrm{NaCl}$, reflecting adaptation to the natural habitat (which can exhibit large variations in salt concentration over various seasons). The $\mathrm{pH}$ range for strain $\mathrm{JA} 125^{\mathrm{T}}$ is $6.0-9.0$, with an optimum at $\mathrm{pH} 7.0-8.0$. The temperature range is $20-35^{\circ} \mathrm{C}$ and the optimum is at $28^{\circ} \mathrm{C}$. Biotin is required as a growth factor. The colour of photosynthetically grown cultures is yellowish brown; when exposed to air, they turn brown, and when they are grown chemoheterotrophically (aerobically in the dark), they appear pink in colour. The whole-cell absorption spectrum (Supplementary Fig. S3a) of strain JA125 showed absorption maxima at 377, 467, 520, 590, 802 and $857 \mathrm{~nm}$, confirming the presence of bacteriochlorophyll $a$. The absorption spectrum for pigments extracted with acetone (Supplementary Fig. S3b) gave maxima at 454 and $484 \mathrm{~nm}$, indicating the presence of the carotenoids spheroidene and spheroidenone.

The DNA G + C content of strain JA125 ${ }^{\mathrm{T}}$ was $58 \mathrm{~mol} \%$ (by HPLC). The phylogenetic relationship between strain $\mathrm{JA} 125^{\mathrm{T}}$ and purple non-sulfur bacteria was examined by means of 16S rRNA gene sequencing: the sequence of the novel isolate formed a separate branch in the cluster of the genus Rhodovulum (Fig. 1) and was distinct from those of 
Table 1. Differentiating characteristics of strain $\mathrm{JA} 125^{\top}$ and species of the genus Rhodovulum

Taxa: 1, strain JA125 ${ }^{\mathrm{T}}$; 2, Rhodovulum marinum (data from Srinivas et al., 2006); 3, Rhodovulum euryhalinum (Kompantseva, 1985; Imhoff \& Trüper, 1992); 4, Rhodovulum strictum (Hiraishi \& Ueda, 1995); 5, Rhodovulum iodosum (Straub et al., 1999); 6, Rhodovulum robiginosum (Straub et al., 1999); 7, Rhodovulum sulfidophilum (Hansen \& Veldkamp, 1973; Imhoff \& Trüper, 1992; Heising et al., 1996); 8, Rhodovulum adriaticum (Neutzling et al., 1984). Organic substrate utilization was tested during photoheterotrophic growth. Acetate, pyruvate and succinate were utilized by all of the taxa. Methanol and benzoate were not utilized by any of the taxa. Motile species exhibit polar flagella. Symbols: +, substrate utilized/present; $(+)$, some strains utilize the substrate and some do not; -, substrate not utilized/absent; NR, not reported.

\begin{tabular}{|c|c|c|c|c|c|c|c|c|}
\hline Characteristic & 1 & 2 & 3 & 4 & 5 & 6 & 7 & 8 \\
\hline Cell diameter $(\mu \mathrm{m})$ & $0.5-0.6$ & $0.6-0.8$ & $0.7-1.0$ & $0.6-1.0$ & $0.5-0.8$ & $0.5-0.8$ & $0.6-1.0$ & $0.5-0.8$ \\
\hline Cell shape ${ }^{\star}$ & $\mathrm{R}$ & $\mathrm{O}$ to $\mathrm{R}, \mathrm{C}$ & $\mathrm{O}$ to $\mathrm{R}$ & $O$ to $\mathrm{R}$ & $\mathrm{O}$ to $\mathrm{R}$ & $\mathrm{O}$ to $\mathrm{R}$ & $\mathrm{O}$ to $\mathrm{R}$ & $\mathrm{R}, \mathrm{C}$ \\
\hline Motility & - & - & + & + & - & - & + & - \\
\hline $\mathrm{NaCl}$ range $(\%)$ & $0.05-7$ & $0.05-8$ & $0.5-10$ & $0.25-3$ & $2.5-5$ & $2.5-5$ & $0-10$ & $1-10$ \\
\hline \multicolumn{9}{|l|}{$\mathrm{pH}$ for growth } \\
\hline Range & $6.0-9.0$ & $5.5-7.5$ & $6.0-8.5$ & $7.5-9.0$ & NR & NR & $5.0-9.0$ & $6.0-8.5$ \\
\hline Optimum & $7.0-8.0$ & $6.0-6.8$ & $\mathrm{NR}$ & NR & 6.5 & 6.5 & NR & NR \\
\hline Chemoorganotrophy & + & + & - & + & + & + & + & - \\
\hline \multicolumn{9}{|l|}{ Temperature for growth $\left({ }^{\circ} \mathrm{C}\right)$} \\
\hline Range & $20-30$ & $25-35$ & NR & $30-35$ & $20-25$ & $25-28$ & NR & $25-30$ \\
\hline Optimum & 28 & 30 & NR & NR & NR & NR & 25 & NR \\
\hline Colour of cell suspension $\dagger$ & YB & ҮВ & Yв & ҮВ & ҮВ & ҮВ & B & B \\
\hline Vitamin requirement $(\mathrm{s}) \ddagger$ & $\mathrm{b}$ & $\mathrm{t}$ & $\mathrm{b}, \mathrm{n}, \mathrm{paba}, \mathrm{t}$ & $\mathrm{b}, \mathrm{paba}, \mathrm{t}$ & $\mathrm{b}, \mathrm{n}$ & $\mathrm{b}, \mathrm{B}_{12}, \mathrm{n}$ & $\mathrm{b}, \mathrm{n}, \mathrm{paba}, \mathrm{t}$ & $\mathrm{b}, \mathrm{t}$ \\
\hline DNA $\mathrm{G}+\mathrm{C}$ content $(\mathrm{mol} \%)$ & 58 & 62 & $62.1-68.6$ & $67.3-67.7$ & 66 & 69 & $66.3-66.6$ & $64.9-66.7$ \\
\hline \multicolumn{9}{|l|}{ Carbon/electron donors } \\
\hline Hydrogen & - & - & NR & NR & + & + & + & - \\
\hline Sulfide & + & - & + & + & + & + & + & + \\
\hline Thiosulfate & + & - & + & + & + & + & + & + \\
\hline Sulfur & - & - & NR & NR & + & + & + & NR \\
\hline Ferrous iron & - & - & - & NR & + & + & + & - \\
\hline Formate & - & - & + & + & - & - & + & + \\
\hline Propionate & - & - & + & + & + & + & + & + \\
\hline Butyrate & - & - & + & + & + & - & + & - \\
\hline Valerate & - & - & + & + & + & - & + & - \\
\hline Caproate & + & - & NR & + & - & - & + & + \\
\hline Ethanol & - & + & + & - & - & - & - & + \\
\hline Lactate & - & + & + & + & + & + & + & + \\
\hline Fumarate & + & + & + & + & + & - & + & + \\
\hline Malate & + & - & + & + & + & + & + & + \\
\hline Citrate & - & - & - & $(+)$ & - & - & - & - \\
\hline Aspartate & + & - & + & - & - & - & - & NR \\
\hline Cysteine & - & - & NR & NR & + & - & NR & NR \\
\hline Glutamate & + & - & + & - & + & + & + & NR \\
\hline Glucose & - & + & + & + & - & - & + & + \\
\hline Fructose & - & + & + & + & - & - & - & - \\
\hline Glycerol & + & + & + & - & - & + & + & + \\
\hline Mannitol & - & + & + & - & + & + & - & - \\
\hline
\end{tabular}

${ }^{\star} \mathrm{C}$, Chains; O, ovoid; R, rod-shaped.

$\dagger \mathrm{B}$, Brown; YB, yellowish brown.

$\neq \mathrm{b}$, Biotin; $\mathrm{B}_{12}$, vitamin $\mathrm{B}_{12} ; \mathrm{n}$, nicotinic acid; paba, p-aminobenzoic acid; t, thiamine.

other genera of purple non-sulfur bacteria. The highest sequence similarities of strain $\mathrm{JA} 125^{\mathrm{T}}$ were found with respect to the type strains of Rhodovulum iodosum (96\%), Rhodovulum adriaticum (95\%), Rhodovulum robiginosum
(95\%), Rhodovulum sulfidophilum (94\%) and Rhodovulum marinum (94\%). Apart from the $16 \mathrm{~S}$ rRNA gene sequence dissimilarity, strain $\mathrm{JA} 125^{\mathrm{T}}$ showed clear phenotypic differences with respect to Rhodovulum species (Table 1) 


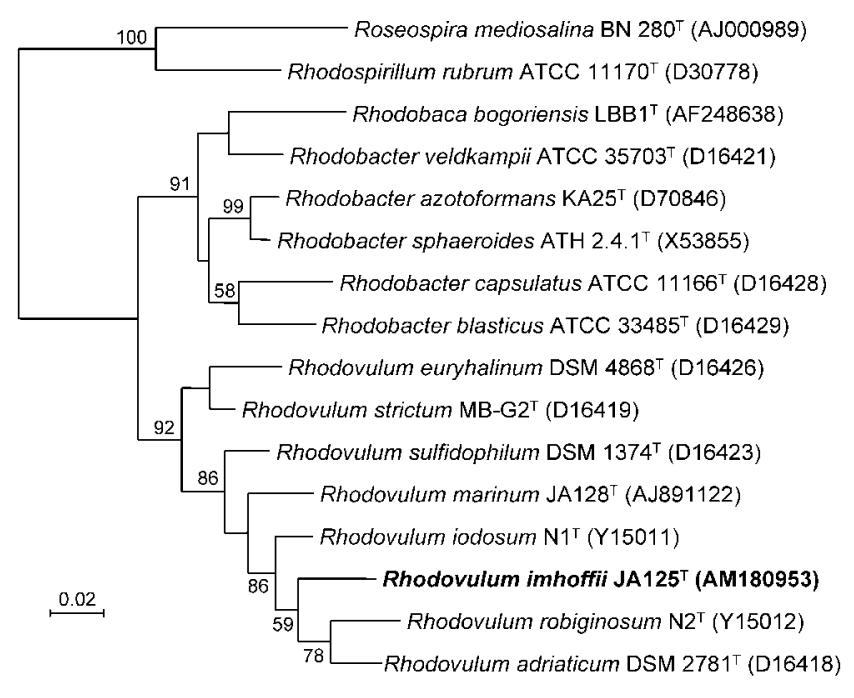

Fig. 1. Dendrogram depicting the phylogenetic relationships of strain $\mathrm{JA} 125^{\mathrm{T}}$ within the family Rhodobacteraceae, determined using 16S rRNA gene sequence analysis using the maximumlikelihood method. Bootstrap values below 50 are not shown. Bar, 2 nucleotide substitutions per 100 nucleotides.

that justify the description of this strain within a novel species, for which the name Rhodovulum imhoffii sp. nov. is proposed.

\section{Description of Rhodovulum imhoffii sp. nov.}

Rhodovulum imhoffii (im.hof'fi.i. N.L. gen. n. imhoffii of Imhoff, named after Johannes F. Imhoff, a German microbiologist who has made a significant contribution to our knowledge of anoxygenic phototrophic bacteria).

Cells are rod-shaped, $0.5 \mu \mathrm{m}$ wide and $1 \mu \mathrm{m}$ long, nonmotile and multiply by binary fission. Gram-negative. Growth occurs under anaerobic conditions in the light (photoorganoheterotrophy) or under aerobic conditions in the dark (chemoorganoheterotrophy). The internal photosynthetic membranes are of the vesicular type. The colour of phototrophic cultures is yellow to brown, whereas aerobic cultures are pink. The in vivo absorption spectrum of intact cells in sucrose exhibits maxima at 377, 467, 520, 590, 802 and $857 \mathrm{~nm}$. The photosynthetic pigments are bacteriochlorophyll $a$ and, probably, carotenoids of the spheroidene series. The type strain is mesophilic (temperature range, 20-35 ${ }^{\circ} \mathrm{C}$; optimum, $28{ }^{\circ} \mathrm{C}$ ), with a $\mathrm{pH}$ optimum at $7.0-8.0$ (range, $\mathrm{pH}$ 6.0-9.0) and a requirement for $\mathrm{NaCl}$ concentrations of $0.5-4.0 \%$ for optimal growth. Photoorganotrophy with various organic compounds is the preferred mode of growth. Acetate, pyruvate and intermediates of the citric acid cycle (except citrate) are good carbon sources. Growth also occurs on glycerol, glutamate, caproate and Casamino acids. Photoautotrophic growth is possible in the presence of sulfide or thiosulfate as the electron donor and $\mathrm{NaHCO}_{3}$ as the carbon source. Biotin is required as a growth factor.
The DNA G+C content is $58 \mathrm{~mol} \%$ (by HPLC). The natural habitat of the known strain is a marine aquaculture pond exposed to light.

The type strain, JA125 ${ }^{\mathrm{T}}\left(=\mathrm{JCM} 13589^{\mathrm{T}}=\mathrm{DSM} 18064^{\mathrm{T}}\right)$, was isolated from water samples from an aquaculture pond near the sea (Bay of Bengal) at Bhimunipatnam, India.

\section{Acknowledgements}

We thank Professor J. F. Imhoff for critical assessment of the manuscript. Financial assistance from the Department of Biotechnology (Government of India) is acknowledged. P. A. K. and T. N. R.S. acknowledge the CSIR (Government of India) for the award of SR fellowships. The skilful assistance of F. Lappe (IFM-GEOMAR, Kiel, Germany) in the molecular analysis is gratefully acknowledged. Financial assistance received under the DST-DAAD exchange program (grant 422-PPP-34105) is acknowledged.

\section{References}

Arunasri, K., Sasikala, C., Ramana, C. V., Süling, J. \& Imhoff, J. F. (2005). Marichromatium indicum sp. nov., a novel purple sulfur gammaproteobacterium from mangrove soil of Goa, India. Int J Syst Evol Microbiol 55, 673-679.

Felsenstein, J. (1989). PHYLIP (phylogeny inference package), version 3.5.1. Distributed by the author. Department of Genome Sciences, University of Washington, Seattle, USA.

Hansen, T. A. \& Veldkamp, H. (1973). Rhodopseudomonas sulfidophila, nov. spec., a new species of the purple nonsulfur bacteria. Arch Microbiol 92, 45-58.

Heising, S., Dilling, W., Schnell, S. \& Schink, B. (1996). Complete assimilation of cysteine by a newly isolated non-sulfur purple bacterium resembling Rhodovulum sulfidophilum (Rhodobacter sulfidophilus). Arch Microbiol 165, 397-401.

Hiraishi, A. \& Ueda, Y. (1994). Intrageneric structure of the genus Rhodobacter: transfer of Rhodobacter sulfidophilus and related marine species to the genus Rhodovulum gen. nov. Int J Syst Bacteriol 44, 15-23.

Hiraishi, A. \& Ueda, Y. (1995). Isolation and characterization of Rhodovulum strictum sp. nov. and some other purple nonsulfur bacteria from colored blooms in tidal and seawater pools. Int J Syst Bacteriol 45, 319-326.

Imhoff, J. F. (1988). Anoxygenic phototrophic bacteria. In Methods in Aquatic Bacteriology, pp. 207-240. Edited by B. Austin. Chichester: Wiley.

Imhoff, J. F. \& Trüper, H. G. (1992). The genus Rhodospirillum and related genera. In The Prokaryotes, 2nd edn, pp. 2141-2155. Edited by A. Balows, H. G. Trüper, M. Dworkin, W. Harder \& K. H. Schleifer. New York: Springer.

Imhoff, J. F., Süling, J. \& Petri, R. (1998). Phylogenetic relationships among the Chromatiaceae, their taxonomic reclassification and description of the new genera Allochromatium, Halochromatium, Isochromatium, Marichromatium, Thiococcus, Thiohalocapsa and Thermochromatium. Int J Syst Bacteriol 48, 1129-1143.

Jukes, T. H. \& Cantor, C. R. (1969). Evolution of protein molecules. In Mammalian Protein Metabolism, pp. 21-132. Edited by H. N. Munro. New York: Academic Press.

Kompantseva, E. I. (1985). New halophilic purple bacteria Rhodobacter euryhalinus sp. nov. Mikrobiologiia 54, 974-982 (in Russian). 
Marmur, J. (1961). A procedure for the isolation of deoxyribonucleic acid from microorganisms. J Mol Biol 3, 208-218.

Mesbah, M., Premachandran, U. \& Whitman, W. B. (1989). Precise measurement of the $\mathrm{G}+\mathrm{C}$ content of deoxyribonucleic acid by highperformance liquid chromatography. Int J Syst Bacteriol 39, 159-167.

Neutzling, O., Imhoff, J. F. \& Trüper, H. G. (1984). Rhodopseudomonas adriatica sp. nov., a new species of the Rhodospirillaceae, dependent on reduced sulfur compounds. Arch Microbiol 137, 256-261.

Pfennig, N. \& Trüper, H. G. (1992). The family Chromatiaceae. In The Prokaryotes, 2nd edn, pp. 3200-3221. Edited by A. Balows, H. G. Trüper, M. Dworkin, W. Harder \& K. H. Schleifer. New York: Springer.

Srinivas, T. N. R., Anil Kumar, P., Sasikala, Ch., Ramana, Ch. V., Süling, J. \& Imhoff, J. F. (2006). Rhodovulum marinum sp. nov., a novel phototrophic purple non-sulfur alphaproteobacterium from marine tides of Visakhapatnam, India. Int J Syst Evol Microbiol 56, $1651-1656$

Straub, K. L., Rainey, F. A. \& Widdel, F. (1999). Rhodovulum iodosum sp. nov. and Rhodovulum robiginosum sp. nov., two new marine phototrophic ferrous-iron-oxidizing purple bacteria. Int $J$ Syst Bacteriol 49, 729-735.

Thompson, J. D., Higgins, D. G. \& Gibson, T. J. (1994). CLUSTAL W: improving the sensitivity of progressive multiple sequence alignment through sequence weighting, position-specific gap penalties and weight matrix choice. Nucleic Acids Res 22, 4673-4680.

Trüper, H. G. \& Pfennig, N. (1981). Isolation of members of the families Chromatiaceae and Chlorobiaceae. In The Prokaryotes: a Handbook on Habitats, Isolation, and Identification of Bacteria, pp. 279-289. Edited by M. P. Starr, H. Stolp, H. G. Trüper, A. Balows \& H. G. Schlegel. New York: Springer. 